THE PATHOLOGY OF THE U.S. ECONOMY 
Also by Michael Perelman

CLASSICAL POLITICAL ECONOMY, PRIMITIVE

ACCUMULATION AND THE SOCIAL DIVISION OF LABOR

FARMING FOR PROFIT IN A HUNGRY WORLD: CAPITAL AND CRISIS IN AGRICULTURE

INFORMATION, SOCIAL RELATIONS AND THE ECONOMICS OF HIGH TECHNOLOGY

KARL MARX'S CRISIS THEORY: LABOUR, SCARCITY AND FICTITIOUS CAPITAL

KEYNES, INVESTMENT THEORY AND THE ECONOMIC SLOWDOWN 


\section{The Pathology of the U.S. Economy}

The Costs of a Low-Wage System

Michael Perelman

Professor of Economics

California State University

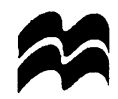

Palgrave Macmillan 
ISBN 978-0-333-65023-3 ISBN 978-1-349-24329-7 (eBook)

DOI 10.1007/978-1-349-24329-7

THE PATHOLOGY OF THE U.S. ECONOMY

Copyright $(\odot)$ 1993, 1996 by Michael Perelman

Reprint of the original edition 1996

All rights reserved. No part of this book may be used or reproduced in any manner whatsoever without written permission except in the case of brief quotations embodied in critical articles or reviews.

For information, address:

St. Martin's Press, Scholarly and Reference Division, 175 Fifth Avenue, New York, N.Y. 10010

First published in the United States of America in 1993

Reprinted (with alterations) 1996

ISBN 978-0-312-12685-8

Library of Congress Cataloging-in-Publication Data

Perelman, Michael.

The pathology of the U.S. economy / Michael Perelman.

p. $\mathrm{cm}$.

Includes bibliographical references and index.

ISBN 978-0-312-12685-8

1. United States-Economic conditions. 2. Industrial relations-

-United States. 3. Monetary policy - United States. Finance-

-United States. 5. Wages-United States. I. Title.

HC103.P417 1993

$330.973-\mathrm{dc} 20$

92-44985

CIP 
To my mother

whose strength and courage has been an inspiration to me 



\section{Contents}

List of Tables and Figures $\quad$ xii

Acknowledgements xii

Introduction to the 1996 Reprint xiii

1 The Setting of the Decline 1

A Preview of the Book 1

The Roots of Economic Mismanagement 3

The Failure of Economic Policy 4

The Role of Crises $\quad 6$

The Challenge Ahead 8

The Golden Age of Capitalism $\quad 10$

Post-War Decline 16

The Falling Rate of Profit 18

The Decline and Falling Profit Rates 19

Poverty and the Distribution of Income 22

The Oil Shock as a Consequence of the Economic

Decline 23

The Decline as a Complex Economy-wide Process 25

Economics and Oversimplification 27

$\begin{array}{ll}\text { Summary } & 28\end{array}$

2 The Attack on Labour Accelerates the Economic Decline $\quad 30$

The Post-War Labour-Management Accord 30

The Breakdown of the Labour-Management Accord 31

Rebellion on the Shop Floor 32

The Social Dynamics of the Economic Decline 34

The Decline and Social Discord 36

How Business Attacked Labour 37

Unemployment and Labour Discipline $\quad 40$

Scorched Earth Economics $\quad 41$

A Catastrophe for Labour $\quad 44$

Adding Insult to Injury 46

The Disastrous Expansion of Low-Wage Service

Employment 
How Businesses' Defeat of Labour Impairs the

Labour Force

Unplanned Fiscal Costs of Labour's Defeat

The Haitian Road to Economic Development

3 Government and the Decline

Keynes and the Credibility of Government

The Dark Side of Keynesian Theory: Military

Keynesianism

The Advantage of Waste

The Rise of a Garrison State

The End of the Excessive Faith in Government

Economic Management

The Abdication of Government from Economic

Responsibility

The Nirvana of Deregulation

The Contraction of the Government and the Economic

Decline

Education, Human Capital and the Economic Decline

The Decline in Public Education as a Cumulative Process 71

Test Scores and the Economic Decline

The Cost of Crippling Public Education

How the Economic Decline Reacts with the Education

System

The Deterioration of the Public Capital Stock

The Social Cost of Deteriorating Public Capital

Transportation and Public Capital

Inadequate Infrastructure and the State of the

U.S. Economy

Infrastructural Decline as Part of the General Decline 85

Future Infrastructural Needs

The Erosion of the Stock of Public Data for the U.S.

Economy

The Strategic Importance of Public Data 90

4 The Role of the Military in the Economic Decline 93

Military Spending as Class Warfare 93

The Benefits of Military Power 96

The Economic Failure of Military Keynesianism 98

The Changing Nature of Military Spending 100 
The Question of Spillovers from Military Research and

Development

The Pernicious Influence of Excessive Military Spending 104

How Military Spending Might Actually Harm the

Military

105

The Class Nature of Military Keynesianism

\section{Keynesian Policy, Monetary Policy, and the}

Weakening of Competition

The Logic of Keynesian Policy and Cumulative

Economic Processes

The Contradictory Nature of the Business Cycle

Keynes's Heresy

Keynesian Policies and Replacement Investment

Capital Widening versus Capital Deepening

Keynesian Policies and the Ageing of the Capital Stock

Monetary Policy and Capital Renewal

High Interest Rates and the Economics of a Short Time

Horizon

The Economics of the Chinese Wall

The Costs of an Ageing Capital Stock

The Economics of Patching

Investing for Rapid Pay-back during the Depression

On the Ageing of the U.S. Capital Stock

The Short Pay-back Period and the Decline in U.S.

Competitiveness

Crisis and Competition in the U.S. Economy

The Overhang of Phantom Capacity

The Elimination of Phantom Capacity

Creative Redeployment of Old Capital Goods

The Elimination of Productive Capacity

The Big Question

\section{Finance, the Falling Rate of Profit and}

Economic Devastation

Finance and the Momentum of the Decline 145

Falling Profits and Rising Interest Rates 146

The Falling Rate of Profit and Increasing Risk 147

What Banks Ideally Do 149

On the Regulation of the Financial System 150 
The Circumvention of Bank Regulation 152

New Dimensions to Speculation 154

Finance and the Decline of U.S. Manufacturing 155

The Falling Rate of Profit and Capital Renewal 157

The Inefficiency of Corporate Takeovers and

Leveraged Buyouts 158

Financial Capital versus Industrial Capital 160

The Unproductive Labour Dissipated in Corporate

Takeovers

Unproductive Labour and the Hobbling of the

Corporate Sector

Financial Services and Unproductive Labour 165

Tracking the Elusive Profit Rate $\quad 168$

The Dual Nature of the Profit Rate 170

7 De-industrialization and the Rise of the Service $\begin{array}{ll}\text { Economy } & 172\end{array}$

Post-industrial Vision $\quad 172$

The Hollow Economy and the Dangers of Post-industrial

$\begin{array}{ll}\text { Utopianism } & 173\end{array}$

The Electronics Industry in the Age of Post-industrialism 175

$\begin{array}{ll}\text { Services and High Technology } & 178\end{array}$

The Demand for Services and the Proximity to

$\begin{array}{lr}\text { Manufacturing } & 179\end{array}$

Does De-industrialization Exist? 182

Is De-industrialization the Rule in Market Economies? 185

Debates over De-industrialization 187

Investment and Taxes $\quad 188$

$\begin{array}{ll}\text { Creativity Again } & 191\end{array}$

8 High Wages, Enlightened Management, and Economic Productivity 192

High Wages as a Defence against De-industrialization 192

The Two Faces of Management-Labour Relations 193

The Internal Politics of Management-Labour Relations 195

The Advantage of a Co-operative Policy toward Labour $\quad 198$

The Economy of High Wages 199

Efficiency Wages 201

The Tradition of the United States as a High-Wage

Economy 202 
High Wages and Protectionism 204

A Test of the Theory of High Falling Wages during the Great Depression

Mitigating Factors

The Dissipation of the Residual Momentum of High Wages

High Wages in an International Context

Surprise! Unions Can Promote Productivity

How Good Management Can Prod Labour to Work Hard

Low Wages and the Structure of De-industrialization

Creative Destruction and Destructive Creativity

\section{Conclusion}




\section{List of Tables and Figures}

Tables

1.1 The Deteriorating Performance of the U.S. Post-war $\begin{array}{ll}\text { Macroeconomy } & 18\end{array}$

1.2 Growth in Profit Rates for Non-Financial Corporations 19

1.3 Real Hourly Earnings in 1977 dollars 22

$2.1 \quad$ Wages and Productivity 56

5.1 Age Distribution of Machine Tools in the United States 132

5.2 International Distribution of Machine Tool Ages (percentages)

\section{Figures}

3.1 Cross-Country Comparison of Productivity Growth and Public Investment to GDP Ratio

7.1 Capital Intensity in Services and Manufacturing

\section{Acknowledgements}

I wish to thank Gary Francis, Robert O'Brien and David Eldridge for their many excellent suggestions. 


\section{Introduction to the 1996 Reprint}

This book insists that systematic problems plague the United States economy. Piecemeal reforms, rather than offering relief, end up doing little, if anything, to correct the underlying malaise.

Almost every administration since the mid-1960s has satisfied itself with minor reforms. In fact, much that has been passing for reform is nothing more than a cruel attempt to shift the burden of adjustment onto the backs of the weakest and least powerful elements in our society.

The Reagan administration stands as the single exception, with its single-minded, almost fanatical insistence that we should take revolutionary action and abandon all government intervention in the economy. Keep in mind that the Reagan administration only selectively adhered to its rhetoric. When the time came to pare back government subsidies to big business, the budget cutters were notable by their absence.

While Reagan was personally popular, his policies were not. Nor, for that matter, were they effective in restoring economic health.

The Bush administration only half-heartedly continued the Reagan legacy. Tired of this market-oriented approach, even the watered-down Bush version, the electorate responded positively to Bill Clinton's call for change, despite considerable qualms about Clinton himself.

The Clinton administration attempted two major reforms. First, it set out to lower the cost of labour and government expenditures by reforming the health care system. What began as a bold proposal, soon became a complicated scheme that could accomplish little other than handing control of health care over to a small core of giant insurance companies. Not surprisingly, it came to naught.

The second thrust of the Clinton administration was to expand demand by integrating the United States economy more deeply into the international economy through the North American Free Trade Agreement and the General Agreement on Tariffs and Trade. These treaties may well exacerbate the crisis. Certainly, they will accelerate the transfer of jobs to countries wheie wages are lower. Perhaps more ominously, these treaties threaten to eliminate considerable economic discretion that might potentially be used to help reverse the decline. 
Neither the failed health care program nor the treaties matched the promise of candidate Clinton's eloquent call for change. As a result, the majority of the minority of the voting public swept the Democrats out of power in both houses of Congress.

Angry with the same symptoms, which I describe in this book, they opted, once again, to vote for a platform of radical change. In fact, many of these new representatives are hell bent on going even further than the original Reagan program.

The majority of the population is bound to be disappointed. Certainly, a madcap speed-up of the ongoing episode of neo-liberalism, or what I describe in this book, the Haitian road to development, will prove disastrous especially for the most vulnerable sections of the population. Working-class people will do little better. Although the current rhetoric resonates about serving the middle class, the poor have so little left to sacrifice that this next stage will certainly intensify the pressure on the middle class.

Most sadly of all, countries around the world are seeking to strengthen their own economies by emulating the policies of the United States. As a result, we may expect to see economies competing more and more on the basis of wage reductions until either the political climate shifts enough to put an end to these destructive policies or we fall into a depression.

No good can come from following the Haitian road in the short-run. Only one question remains: what reaction will follow the inevitable disappointment? 